\title{
Topical application of honey: An alternative way of treating wounds in veterinary medicine?
}

\author{
Maayke Ruiter and Astrid B. M. Rijkenhuizen \\ Department of Equine Sciences, Faculty of Veterinary medicine, Utrecht University.
}

\begin{abstract}
Summary
Honey is essentially a concentrated sugar solution, containing mainly fructose and glucose, but also maltose, sucrose, phenolic acids, enzymes such as glucose oxidase, catalase and peroxidase, vitamins and minerals. It has antibacterial effects, contains antioxidants, decreases inflammatory edema, stimulates the immune response, stimulates the neovascularisation and the multiplication of fibroblasts and epithelial cells, reduces the need for surgical debridement, clears of foul odour, increases the flow of lymph and forms an energy source for epithelial cells in a wound area. Honey has antibacterial activity due to the production of hydrogen peroxide after dilution with water, its high osmolarity, acidity and phytochemical compounds. Besides these direct antibacterial effects, honey applied to a wound forms a viscous, protective and physical barrier against invading pathogens. Interesting side qualities of honey are: a diminishing effect on tumor implantation and prevention of peritoneal adhesions. In veterinary medicine honey, in it's different constitutional forms, makes a good non-antibiotic alternative for products currently used in wound therapy. Honey or honey based products can be applied to grazes, abrasions and erosions in the inflammatory and debridement phase: the inflammatory response is supported and debridement accelerated. Granulation tissue can then form more rapidly and epithelization of the tissue is promoted. It is also a good opportunity for treating a acute or chronic dermatitis. In older wounds that are difficult to manage with conventional therapy like burn wounds or infected surgical wounds honey is also effective, as it has a debriding, antibacterial and immune response stimulating effect, initiating the wound healing process.
\end{abstract}

Keywords: wound treatment, honey, wound healing, topical application, traumatology

\section{Lokale Anwendung von Honig: Ein alternativer Weg der Wundbehandlung in der Tiermedizin?}

Honig stellt im Wesentlichen eine konzentrierte Zuckerlösung dar, die überwiegend Fruktose und Glukose, aber auch Maltose, Sukrose, Phenolsäuren, Enzyme wie Glucoseoxidase, Katalase und Peroxidase sowie Vitamine und Mineralien enthält. Honig hat antibakterielle Wirkung, enthält Antioxidantien, vermindert entzündliche Ödeme, stimuliert die Immunantwort, Neovaskularisation und Multiplikation von Fibroblasten und Epithelzellen, reduziert die Notwendigkeit für chirurgisches Debridement, vermeidet fauligen Wundgeruch, verbessert den Lymphfluss und stellt eine Energiequelle für die Epithelzellen im Wundgebiet dar. Die antibiotische Aktivität beruht auf der Produktion von Hydrogenperoxid nach der Verdünnung mit Wasser, auf seiner hohen Osmolarität, Azidität und seinen phytochemischen Inhaltsstoffen. Neben dieser direkten antibakteriellen Wirkung bildet Honig nach der Applikation auf eine Wunde eine visköse, protektive und physikalische Barriere gegen eindringende Pathogene. Interessante Nebeneffekte sind ein reduzierender Effekt auf Tumorimplantation und die Verhinderung peritonealer Verwachsungen. In der Tiermedizin stellt Honig in seinen unterschiedlichen Formen eine interessante Alternative zu den üblicherweise in der Wundbehandlung eingesetzten Mitteln dar. Honig oder auf Honig basierende Produkte können auf Riss- oder Schürfwunden und Erosionen in der entzündlichen Phase aufgebracht werden. Dabei wird die Entzündungsantwort unterstütz† und das natürliche Wunddebridement beschleunigt. In der Folge wird die Granulationsgewebsbildung Epithelisierung gefördert. Honig eigent sich zudem gut zur Behandlung akuter vund chronischer Dermatitiden. Auch bei älteren, mit konventioneller Therapie schwer zu behandelnden Wunden wie Brandwunden und infizierten chirurgischen Wunden ist Honig aufgrund seines wundreinigenden, antibakteriellen und immunstimulierenden Effekts wirksam, indem er den Heilungsprozess initiiert und unterstützt.

Schlüsselwörter: Wundbehandlung, Honig, Wundheilung, lokale Anwendung, Traumatologie

\section{Introduction}

Honey has been applied in medicine in woundhealing for centuries. A first reference to its use was on a Sumerian tablet, found at Nippur in Iraq, dating from about 2000 BC. It listed several prescriptions for ointments, in one honey and water were used to make a medical powder (Crane et al. 1975). In the ancient Egypt, honey was used in wound treatment mixed with fat and in the middle ages fat and proteins were added to make it suitable for similar purposes (Lusby et al. 2002, Majno 1975).

During the Second World War, antibiotics made a break through appearance in the medical world and with this, the use of honey was partially forgotten. For a long period after this, it was only used in alternative wound healing medicine (Eilders et al. 2003).

Honey has been rediscovered in the eighties for use in human medicine. As there are more and more strains of bacteria that are resistant against antibiotics, new methods for treatment of infected wounds are necessary. Honey a product of nature, seems to have many of the properties that the medical world is looking for to heal wounds; it contains antioxidants, has antibacterial properties and has effect on the immune response. It is non-toxic, non-irritant, easy available and cheap. The aim of this paper is to give an overview of the effects that honey has on wound healing and to find out if honey has a potential for treating wounds in veterinary medicine. 


\section{Honey}

Honey is essentially a concentrated sugar solution, containing mainly fructose and glucose, but also maltose, sucrose, phenolic acids, enzymes such as glucose oxidase, catalase en peroxidase, vitamins and minerals (Nagai et al 2001). Bees collect nectar from flowers and bring it to their hive, there it is deposited into a wax cell. Nectar collected from different species of flowers creates honey of a blended type. When one flower species forms the main source of nectar in the bee's habitat, honey is made of a single flower type, like Australian Jelly Bush and New Zeeland Manuka honey, both made from the nectar of leptospermum spp. (tea trees).

Enzymes are added to the nectar from glands in the bees honey stomach, adding specific characteristics, like some of its antibacterial traits. Water evaporates from the nectar, reducing the water concentration to $17 \%$, by fanning of the bees and the warmth of the hive (Namias 2003). After a period of ripening the end product is honey.

For medical purposes only sterile honey free of additives and pesticides can be used. To retain the active enzymes in medical honey, gamma radiation should be used for sterilization (Molan et al. 1996).

Products containing honey that are available for use in the veterinary market are, Vetramil ${ }^{\circledR 1}$, L-Mesitran ${ }^{\circledR}$ Veterinary ${ }^{2}$, Honeysoft $^{\circledR 3}$, HNZ (Honey New Zealand) active UMF(Unique Manuka Factor) Manuka honey ${ }^{\circledR 4}$.

Variation in effectiveness exist between different honeys due to level of hydrogen perioxide and floral origin (Lusby et al 2002).

Properties that make honey a useful product are: antibacterial properties, stimulation of wound healing and some additional miscellaneous effects

\section{Antibacterial properties}

The most remarkable quality of honey is that it is very effective in quickly getting infected wounds sterile, without the sideeffects of antibiotics, even with antibiotica restistant strains (Zander et al. 1975, Crane 1975, French et al. 2005). Wounds infected with Staphylococcus aureus in buffalo treated with honey, healed faster and showed less signs of inflammation when compared to those treated with antibiotics (Gupta et al. 1993). In human patients wounds that were not infected with bacteria remained so when treated with honeyimpregnated gauzes. Wounds that were infected and showed signs of inflammation became non-infected wounds within one week of starting treatment (Efem 1988).

Honey has antibacterial activity due to the production of hydrogen peroxide after dilution with water, its high osmolarity, acidity and phytochemical compounds. Besides these direct antibacterial effects, honey applied to a wound forms a viscous, protective and physical barrier against invading pathogens (Efem et al. 1988, Subrahmanyam 1991, Lusby et al. 2005).

The production of hydrogen peroxide is the main reason why honey has antibacterial properties. Honey contains glucose oxidase, an enzyme that originates from the glands of the bee. When honey is diluted with water or wound exudate, glucose oxidase becomes active and breaks down glucose into hydrogen peroxide and oxygen. As hydrogen peroxide breaks down further, hydroxyl radicals are formed that have bactericide activity (Lord 2000, Matthews et al. 2002). Hydrogen peroxide (3\% solution) is already used as a disinfectant (Molan 2001a). At this concentration however, it is cytotoxic and not suitable for wound treatment. In honey, the concentration of hydrogen peroxide produced is about 1000 times less than the above, at about $1 \mathrm{mmol} / \mathrm{L}$. This very low dose, which is continually produced as long as glucose oxidase is active, does still have antibacterial effect, but is not cytotoxic (Molan 2001a). Optimal dilution concentrations of honey, for the production of hydrogen peroxide have been found to lie between 30\%- 50\%. (Bang et al. 2003).

Wound infecting species of bacteria such as Escherichia coli, Proteus mirabilis, Pseudomonas aeruginosa, Salmonella typhimurium, Seratia marcescens, Staphylococcus areus and Streptococcus pyogenes have been used in studies to test their sensitivity against the hydrogen peroxide activity of honey. At concentrations of $11 \%$ honey in a solution, the growth of all seven species was completely inhibited (Willix et al. 1992).

The high osmolarity of honey has antibacterial effects for most pathogens. There is a strong interaction between the sugar molecules and water, leaving very few water molecules to sustain growth of micro organisms (Kalam et al. 2003, Lusby et al. 2002).

The acidity of honey (pH of 3.6-3.7 due to its high gluconic acid content) contributes to the antibacterial effect and promotes wound healing (Matthews et al. 2002, Kaufman et al. 1985).

In some types of honey, like Manuka honey from New Zealand and Jelly Bush honey from Australia, another antibacterial trait has been identified; often referred to as the phytochemical factor or non-peroxide activity (Lord 2000). These honeys prevent bacterial growth after the honey has been diluted (excluding high osmolarity), and after catalase (an enzyme that destroys hydrogen peroxide) has been added to the honey (Weston et al. 1999). Manuka honey has shown to completely inhibit the growth of Staphylococcus aureus at a concentration of $1.8 \%$, due to non-peroxide activity (Willix et al. 1992). Whereas this property has only been described for some specific honey types that come from a certain area, it is believed to originate from the plants on which the bees feed: the Tea tree (Molan 2001b). However, Weston (2000a), and Zaghloul et al (2001) showed these effects regardless of the region from which the honey was obtained. The factors responsible for these effects are not yet completely identified. Phenolic acids and flavonoids found in honey exhibit antibacterial activity (Weston 2000b). In varying types of Manuka honey different levels of these substances may explain the non-peroxide antibacterial effects of some variants. The phenolic components that were identified by high performance liquid chromatography are identical in Manuka honey with a high level of non-peroxide antibacterial activity, to those found in Manuka honey with no non-peroxide antibacterial activity. The phenolic components of Manuka honey may therefore contribute to the observed antibacterial activity but cannot account for all the non-peroxide antibacterial activity found in (Weston 2000a). Weston (2000a) hypothesised that 
the observed difference in antibacterial effect might be due to very high levels of hydrogen peroxide produced in the honey which is not totally destroyed by catalase already present in the honey or the amount of catalase added prior to the assay, thereby leaving a residual hydrogen peroxide activity. It has however been shown that even after adding a ten fold overdose of catalase prior to an assay antibacterial activity still remains (Snow and Manley-Harris 2004).

Not all Manuka honey variants, have this non-peroxide activity. In order to find the agent that gives some Manuka honey non-peroxide antibacterial activity, more research still needs to be undertaken.

\section{Properties of honey that contribute to wound healing}

Hydrogen peroxide, produced in low concentrations in diluted honey, enhances the effects that hydrogen peroxide, produced as part of the normal inflammatory response to injury or infection in the body, already has (Burdon 1995, Bang et al. 2003, Matthews et al. 2002).

It stimulates the development of new capillaries in wound tissue and the multiplication of fibroblasts and epithelial cells. Another effect is that hydrogen peroxide reduces the necessity for surgical debridement as it activates protein-digesting enzymes that break down dead or dying tissue (Efem et al. 1988, Lord 2000, Molan 1998, Subrahmanyam 1991).

High concentrations of glucose in honey form an energy source for epithelial cells (Matthews et al. 2002). The rich supply of glucose has an attractive side effect: odour neutralizing effect. Pathogens usually feed on amino acids from the wound producing malodorous compounds, like ammonia, amines and sulphur compounds. When honey is applied to a wound, the glucose is used as an alternative energy source by the bacteria leaving lactic acid as an end product, which does not have a foul odour (Lusby et al. 2002, Matthews et al. 2002).

Due to the high osmolarity of honey, the lymph flow increases to the wound area, providing nutrification for the traumatized tissue and reducing oedema around wounds (Efem 1988, Gupta et al. 1993, Lusby et al. 2002, Molan 2001 a).

Honey contains high levels of antioxidants that protect tissue from being damaged by free radicals (Aliadi et al. 2004, AlMamary et al. 2002, Nagai et al. 2001). The phenol fraction of honey contains the most antioxidants. Vitamin C, vitamin $E$, enzymes such as catalase, peroxidase and, phenolic compounds are all found in honey and have antioxidative properties. These aqueous and lipophilic antioxidants can interact with one another, making honey an ideal natural antioxidant that can act at various cellular sites protecting tissue from damage by free radicals (Aliadi et al. 2004, Blasa et al. 2006). Particularly buckwheat honey shows high antioxidative activity. It is suggested that high antioxidative activity occurs in honeys with dark colour, such as buckwheat, and weak activity with light coloured honey (Acacia, Japanese bee) (Nagai et al. 2001). The amount of activity within a honey varies widely and is mostly dependant of the total phenolic content. This could form a parameter for its quality in wound healing (Aljadi et al. 2004).
The immune response necessary for wound healing is activated by honey, by stimulating cytokine production of monocytes. The release of cytokines initiates the tissue repair process as well as the immune response to infection (Abuharfeil et al. 1999, Slavin 1996, Tonks et al. 2001, Tonks et al. 2003). Honey also reduces the production of reactive oxygen intermediates ( $\mathrm{ROIs}$ ) and may help to limit tissue damage by activated macrophages during the healing process (Tonks et al 2001). It also enhanced the release of tumor necrosis factor-alpha (TNF- $\alpha$ ), interleukin (IL) 1 B and IL-6 from monocytes, which are pro and antiinflammatory (Tonks et al 2001, 2003). The effects on cytokine production was not seen in all honeys.

Honey has a mitogenic effect on both B-and T- lymphocytes. It stimulates the proliferation of B-and T- lymphocytes in the absence of mitogens (concovalin $A$, phytohemagglutinin and lipopolysaccharides) and therefore must contain lymphomitogen(s). This effect does not depend on the concentration of honey. It is still unknown if one mitogen or several are present (Abuharfeil et al. 1999).

Wounds treated with honey have been shown to heal much faster in animal models than the controls that were used in these studies, such as saline solution or antibiotics (Bergman et al. 1983, Gupta et al. 1993, Oryan et al. 1998). When honey is compared to other substances which are used in wound management such as EUSOL (Edinburgh University solution of Lime, a calcium hypochlorite solution) (Okeniyi et al. 2005, Dow 2006), polyurethane film (OpSite ${ }^{\circledR}$ ) (Subrahmanyam 1993a), aminotic membrane (Subrahmanyam 1994) and silver sulfadiazine (Subrahmanyam 1998), epithelization occurs more rapidly in honey treated groups.

The healing effect that honey has is thus obtained by the production of hydrogen peroxide, its glucose and antioxidant content, increase of lymph flow, and stimulation of the immune response on different levels.

\section{Additional effects found in clinical studies}

There have also been a few studies that use honey for a very specific purpose, mostly not directly related to wound healing. They form an interesting group of qualities that may not be helpful directly in wound healing, but could prove to be useful in future veterinary practice.

Honey has a diminishing effect on tumor implantation. Tumor implantation can occur after laparoscopic removal of tumors at trocar sites. Reports of trocar site reoccurrence reduced the use of laparoscopy in malignant disease. In mice, wounds inoculated with tumor and coated with honey before and after inoculation, showed no macroscopic signs of tumor implantation. On histopathological examination of the wound area eight out of thirty mice had tumor implantation on the inoculation sight. In the control group, all mice had macroscopic and histopathological changes (Hamzaoglu et al. 2000). The honey used did not protect the mice completely, but there were no negative side affects registered and therefore honey at least forms a partial barrier against tumor implantation.

Honey is thought to prevent peritoneal adhesions if left in the abdominal cavity after surgery. In a study the honey treated group showed far less adhesions and the adhesions that were 
presents were less severe than those found in the control group. The mechanism behind this remains to be found but two explanations are suggested. The first being that honey forms a physical barrier between the peritoneal layers, preventing adhesion. Secondly, honey may inhibit the production of peritoneal plasminogen activator, which was earlier proven important in the process of peritoneal adhesion (Aysan et al. 2001).

The last remarkable trait is the use of honey in skin graft storage. Skin is most commonly stored in glycerol solutions of $85 \%$ and kept cool at $4{ }^{\circ} \mathrm{C}$. Using this method, skin grafts may be preserved for up to 5 years (Hermans et al. 1996, Nassau 2000). When skin grafts stored in honey at $4{ }^{\circ} \mathrm{C}$ were taken out of the honey, they were firm and yellow brown. After re-establishing the grafts in normal saline, the texture became normal and the colour improved. There was no autolysis of the graft with storage up to twelve weeks in honey at room temperature or $4{ }^{\circ} \mathrm{C}$. Graft uptake ranged from $100 \%$ (six week storage) to 80\% (twelve week storage) (Subrahmanyam 1993b).

In the western world honey will most likely never form an alternative for skin preservation, but it may prove useful in less developed countries where resources are scarce. Honey is readily available, and can be used for skin graft storage for short periods, without the need of cooling.

\section{Honey's use in wound treatment}

When honey is applied for woundhealing necrotic tissue is best resected, wounds are rinsed preferably with saline solution or clean tap water. Once the wound area has dried honey or a honey containing cream/dressing can be applied. Any cavities and depressions that may be present in deeper wounds must be filled with honey before applying dressing pads. Routinely, dressings are changed daily, but up to three times daily may be necessary when starting treatment on heavily exuding wounds, as most of honey's beneficial traits are reduced when it becomes diluted with large amounts of exudate. The frequency of dressing changes can be adjusted as seen fit in the course of the wound healing process (Matthews et al. 2002, Molan 2001a; Molan 2001 b).

\section{What products can be used in wound therapy}

There are a few wound-healing products available in which honey is the main ingredient. In different formulas such as creams, ointments and dressings. Commercially available products are Vetrami ${ }^{\circledR}$, Honeysoft $^{\circledR}$, L-Mesitran ${ }^{\circledR}$ Veterinary and HNZ active UMF Manuka honey ${ }^{\circledR}$.

Vetramil ${ }^{\circledR}$ is a cream made from honey and some essential oils. It is a licensed veterinary product. The factory produces its own honey form its own bee stock. The honey is selected for its high enzyme contents and low $\mathrm{pH}$, both traits having a role in antibacterial activity. The producer claims its honey also has non-peroxide antibacterial activity, there are however no published articles on this. Vetrami ${ }^{\circledR}$ contains no additives and is sterilized with gamma radiation.

Honeysoft ${ }^{\circledR}$ is a dressing that is preimpregnated with honey. The honey used is ECO certified and imported from Chilli and gamma radiated. It is free of herbicides, pesticides and heavy metals. It has no known non-peroxide antibacterial activity, but does contain glucose oxidase to produce low levels of hydrogen peroxide giving the honey antibacterial activity. No other products are added to the dressing but the honey.

L-Mesitran ${ }^{\circledR}$ Veterinary is a honey based cream. The honey used in Mesitran products is sterile, free of additives and has non-peroxide antibacterial activity. It contains not only honey but also aloë, calendula, zinkoxide, medilan and vitamins all contributing to rapid wound healing. The firm claims to only need very little product when applied to wounds. Honey impregnated dressings are also available but registered for human medicine (Putte 2002, Overgauw et al. 2006).

Pure honey can also be used, it is less practical, as it is not produced in tubes or dressings that make a product easy to apply. Its has the disadvantage that it may contain Bacillus sp. and Clostridium, or pesticides, antibiotic residues such as tetracyclines used on bees (Overgaauw and Kirpensteijn 2006).

HNZ (Honey New Zealand) active UMF Manuka honey may be very good to use as it has been proven to have non-peroxide antibacterial activity as well as all the other qualities that other honeys posses. It is available in different concentrations referring to its non-peroxide activity (unique Manuka factor). This Unique Manuka factor can range from 10 to 25 and refers to the equivalent antibacterial strength of a $10 \%$ $25 \%$ carbolic acid solution. HNZ active UMF Manuka honey is put on the market with a guarantee of being bacteria free, but the supplier cannot specify any means by which this is attained.

As a wounddressing Honeysoft ${ }^{\circledR}$ might be the most practical products to use. They are packaged to guarantee sterility. When dealing with larger exuding wounds that need more frequent dressing changes, perhaps self-prepared dressings soaked in pure honey or a honey based cream are better to use. Never use honey that is bought as a food product in the supermarket. This honey is pasteurized to make it safe for human consumption, denaturing all the enzymes that give raw honey its special properties. It would be like using a concentrated sugar solution on a wound, only having the benefits of high osmolarity to prevent bacterial growth and stimulate lymph flow.

\section{Conclusion}

Honey accelerates wound healing on many different levels. It has antibacterial effects, contains antioxidants, stimulates the immune response, reduces the need for surgical debridement, clears of foul odour, increases the flow of lymph and forms an energy source for epithelial cells in a wound area. It can be concluded that in veterinary medicine honey, in it's different constitutional forms, makes a cost effective alternative for products currently used in wound therapy. Honey or honey based products can be applied to grazes, abrasions and erosions in the inflammatory and debridement phase: the inflammatory response is supported and debridement accelerated. Granulation tissue can then form more rapidly and epithelization of the tissue is promoted. It is also a good opportunity for treating a dermatitis. In older wounds that are difficult to manage with conventional therapy like burn wounds or infected surgical wounds honey is also very effective, as it has a debriding, antibacterial and immune response stimulating effect, initiating the wound healing process. 
Different types of wounds will always need different means of treatment. It is up to the clinicians experience and knowledge to make the choice between the different products available.

\section{Manufacturer's addresses}

1 www.dermaprof.nl, Honeysoft ${ }^{\circledR}$

2 www.bfactory.nl, Revamil ${ }^{\circledR}$

3 www.triticum.org, L-Mesitran ${ }^{\circledR}$ Veterinary

4 www.starremedies.nl

\section{Literature}

Abuharfeil N., Al-Oran R. and Abo-shehada M. (1999): The effect of bee honey on the proliferative activity of human B-and T-lymphocytes and the activity of phagocytes. Food and agricultural immunology 11, 169-177

Aljadi A. M. and Kamaruddin M. Y. (2004): Evaluation of the phenolic contents and antioxidant capacities of two Malaysian honeys. Food chemistry 85, 513-518

Aysan E., Ayar E., Aren A. and Cifter C. (2002): The role of intraperitoneal honey administration in preventing post-operative peritoneal adhesions. Obstetrics \& gynecology 104, 152-155

Bang L. M., Buntting C. and Molan P. (2003): The rate of dilution on the rate of hydrogen peroxide production in honey and its implications for wound healing. The Journal of alternative and complementary medicine 9, 267-273

Bergman A., Yanai J., Weiss J., Bell D. and David M. P. (1983): Acceleration of wound healing by topical application of honey. The American journal of surgery 145, 374-376

Blasa M., Candiracci M., Accorsi A., Piancentini M. P., Albertini M. C. and Piatti E. (2006): Raw Millefiori honey is packed full of antioxidants. Food chemistry 97, 217-222

Burdon R. H. (1995): Superoxide and hydrogen peroxide in relation to mammalian cell proliferation. Free radical biology \& medicine; $18,775-794$

Crane E. (1975): Honey, a comprehensive study. Published in cooperation with the bee research association Chalfont St. Peter, Buckinghamshire, England.

Dow G. (2006): Adjunctive measures for the management of the diabetic foot. www.coa-aco.org.

Efem S. E. E. (1988): Clinical observations on the wound healing properties of honey. British journal of surgery 75, 679-681

Eilders M. and Zwaga S. (2003): Honing de bij als wondverzorger. Pharmaselecta 17

French V. M., Cooper R. A. and Molan P. C. (2005): The antibacterial activity of honey against coagulase-negative staphylococci. Journal of antimicrobial chemotherapy 56, 228-231

Gupta S. K., Singh H., Varshney A. C., Prakash P. and Singh S. P. (1993): Biochemical alterations during wound healing under the influence of natural honey and ampicillin in buffaloes. Indian veterinary journal 70, 45-47

Hamzaoglu I., Saribeyoglu K., Durak H., Karahasanoglu T., Bayrak I., Altug T., Sirin F. and Sariyar M. (2000): Protective covering of surgical wounds with honey impedes tumor implantation. Archives of surgery 135, 1414-1417

Hermans R. P., Hoekstra M. J., Kropman G. M. and Koenderink J. A. (1996): The history and function of the euro skin bank. Annals of burns and fire disasters 9, 36-38

Kalam A., Ahmed J., Hoekstra M. J., Hage J. J. and Karim R. B. (2003): Honey-Medicated dressing: Transformation of an ancient remedy into modern therapy. Annals of plastic surgery 50, 143-148

Kaufman T., Eichenlaub A. H., Angel M. F., Levin M. and Futrell J. W. (1985): Topical acidification promotes healing of experimental deep partial thickness skin burns: a randomized double-blind study. Burns 12, 84-90

Lord A. (2000): Sweet healing. New scientist 167, 32-35

Lusby P. E., Coombes A. L. and Wilkinson J. M. (2002): Honey: A potent agent for wound healing. Wound care (J WOCN) 29, 295-300.

Lusby P. E., Coombes A. L. and Wilkinson J. M. (2005): Bacterial activity of different honeys against pathogenic bacteria. Archives of medical research 36, 464-467

Al-Mamary M., Al-Meeri A. and Al-Habori M. (2002): Antioxidant activities and total phenolics of different types of honey. Nutrition research 22, 1041-1047
Majno G. (1975): The healing hand, man and wound in the ancient world. Harvard university press, Cambridge, Massachusetts, USA.

Matthews K. A. and Binnington A. G. (2002): Wound management using honey. Compendium on continuing education for the practising veterinarian $24,53-59$

Molan P. C. and Allen K. A. (1996): The effect of gamma-irradiation on the antibacterial activity of honey. Journal of pharmacy and pharmacology 48, 1206-1209

Molan P. C.(1998): A brief review of the use of honey as a clinical dressing. The Australian Journal of Wound Management 6, 148-158

Molan P. C. (2001a): Potential of honey in the treatment of wounds and burns. American journal of clinical dermatology 2, 13-19

Molan P. C. (2001b): Honey as a topical antibacterial agent for the treatment of infected wounds. World wide wounds.

Nagai T., Sakai M., Inoue R., Inoue H. and Suzuki N. (2001): Antioxidative activities of some commercially honeys, royal jelly, and propolis. Food Chemistry 75, 237-240

Namias N. (2003): Honey in the management of infections. Surgical infections 4, 219-226

Nassau van J. F. (2000): Euro skin bank. TransParant 8, 12-13

Okeniyi J. A. O., Olanbajo O. O., Ogunlesi T. A. and Oyelami O. A. (2005): Comparison of healing of incised abscess wounds with honey and eusol dressing. The journal of alternative and complementary medicine 11,511-513

Oryan A. and Zaker S. R. (1998): Effects of topical application of honey on cutaneous wound healing in rabbits. Journal of veterinary medicine $45,181-188$

Overgauw P. A. M. and Kirpensteijn J. (2006): Application of honey in the treatment of skin wounds. European Journal of companion animal practitioners 16, 17-19

Putte J. van der (2002): Honing: onomwonden wondverzorging, Honing: veel meer dan een pleister op de wonde. Medisch contact, Nederlands tijdschrift voor Dermatologie en Venereologie en Verpleegkunde Nieuws

Slavin J. (1996): The role of cytokines in wound healing. Journal of pathology 178, 5-10

Snow M. J. and Manley-Harris M. (2004): On the nature of nonperoxide antibacterial activity in New Zealand Manuka honey. Food chemistry 84, 145-147

Subrahmanyam M. (1991): Topical application of honey in treatment of burns. British journal of surgery 78, 497-498

Subrahmanyam M. (1993a): Honey impregnated gauze versus polyurethane film (OpSite ${ }^{\circledR}$ ) in the treatment of burns- a prospective randomized study. British journal of plastic surgery 46, 322-323

Subrahmanyam M. (1993b): Storage of skin grafts in honey. The Lancet 341, 63-64

Subrahmanyam M. (1994): Honey-impregnated gauze versus amniotic membrane in the treatment of burns. Burns 20,331-333

Subrahmanyam M. (1998): A prospective randomise clinical and histological study of superficial burn wound healing with honey and silver sulfadiazine. Burns 24, 157-161

Tonks A., Cooper R. A., Price A. J., Molan P. C. and Jones K. P. (2001): Stimulation of TNF-alpha release in monocytes by honey. Academic press 14, 240-242

Tonks A. J., Cooper R. A., Jones K. P., Blair S., Parton J. and Tonks A. (2003): Honey stimulates inflammatory cytokine production from monocytes. Cytokine 21, 242-247

Weston R. J., Mitchell K. R. and Allen K. L. (1999): Antibacterial phenolic components of New Zealand Manuka honey. Food Chemistry 64, 295-301

Weston R. J. (2000a): The contribution of catalase and other natural products to the antibacterial activity of honey: a review. Food Chemistry 71, 235-239

Weston R. J., Brocklebank L. K. and Lu Y. (2000b): Identification and quantitative levels of antibacterial components of some New Zealand honeys. Food Chemistry 70, 427-453

Willix D. J., Molan P. C. and Harfoot C. G. (1992): A comparison of the sensitivity of wound infecting species of bacteria to the antibacterial activity of Manuka honey and other honey. Journal of applied bacteriology 73, 388-394

Zander M. (1975): Der Honig. Published by Eugen Ulmer, Stuttgart, Germany

Astrid B. M. Rijkenhuizen, PhD, dipl. ECVS, dipl. RNVA

Department of Equine Science, Utrecht University

Yalelaan 12, 3584 CM Utrecht, The Netherlands

a.riikenuizen@uu.nl 